\title{
Skipulag fiskveiða og sköpun arðs: Hver eru tengslin?
}

\author{
Birgir Pór Runólfsson ${ }^{1}$
}

\begin{abstract}
Ágrip
Hér er pess freistað að varpa ljósi á pað hagræna samhengi sem skapar arð í fiskveiðum og útskýra um leið hugtök sem par koma við sögu. Hugtökin renta og auðlindarenta hafa mjög verið notuð í pessu sambandi. Saga hugtakanna er rakin stuttlega og sá fjölbreytilegi skilningur sem fræðimenn hafa lagt í pau, og hin ýmsu afbrigði rentuhugtaksins skýrgreind. Pá er stuttlega fjallað um hagnað og tengsl hans við rentu. Megináhersla er á að útskýra hvers vegna rangt sé að álykta að tilvist svokallaðrar auðlindarentu hafi alfarið með ástand auðlindar að gera eða aðgerðir stjórnvalda til takmörkunar. Skipulag fiskveiða sem byggir á eignarrétti er mikilvægasta forsenda pess að skapa arð af fiskveiðum og raunar auðlindanýtingu yfirleitt. Nægjanlega sterkar eignarréttur parf að vera til staðar svo unnt sé að forðast svokallaðan „harmleik almenninga.“ Pá er jafnframt rökstutt að tilvist auðlindarentu byggi fyrst og fremst á hæfileikum peirra er veljast til að starfa í sjávarútveginum, á hugviti og framtaksemi peirra, og peim hvata sem peir hafa til að hámarka pað virði sem hægt er að búa úr afurðum af nýtingu fiskistofna.
\end{abstract}

\begin{abstract}
The purpose here is to shed some light on the creation of economic rent and profit in fisheries. This is done by explaining various concepts, such as economic rents and resource rents which are often used in this context without clear definition. We outline briefly the history of these concepts and review the various different definitions and meaning that scholars have attributed to these concepts. A brief discussion on the relation of economic profits and rents follows. The main focus is then to explain why it is inappropriate to conclude that the existence of so-called resource rent has entirely to do with the state of the fisheries resource or to government actions that limit access to harvesting. Rather, it is the rights based (re)organization of the fisheries that is the most important prerequisite for rent creation. Sufficiently strong property rights must be instituted in order to avert the "tragedy of the commons." It is further argued that the existence of resource rents in the fisheries relies primarily on the ability of those who work in the industry, their ingenuity and entrepreneurial activities, and appropriate incentives that these rights give to maximize the value of the catch and the products derived therefrom.
\end{abstract}

JEL flokkun: D23, D3, D72, Q22, Q28,

Lykilhugtök: Aflahlutdeildarkerfi, arðsköpun, renta, eignarréttur, fiskveiðistjórnun,

\footnotetext{
${ }^{1}$ Höfundur er dósent í Hagfræðideild Háskóla Íslands. Höfundur vill pakka Ragnari Árnasyni og Daða Má Kristóferssyni fyrir yfirlestur og góðar ábendingar, og jafnframt ritrýnum ábendingar peirra.
} 
Innleiðing aflahlutdeildarkerfis, svokallaðs kvótakerfis, í fiskveiðum hefur haft mikil áhrif á afkomu greinarinnar. Раð hefur leitt til hagræðingar og aukinnar verðmætasköpunar. Í stað neikvæðrar afkomu greinarinnar að jafnaði er afkoman nú er jákvæð, jafnvel verulega jákvæð, að jafnaði. Rekstrarafgangur hefur pannig tekið við af rekstarhalla. ${ }^{2}$

Í hagfræði er pessari auknu verðmætasköpun yfirleitt lýst með almennum hugtökum eins og hagnaði eða arði. Sumir hagfræðingar hafa kosið að lýsa pessari auknu verðmætasköpun sem „,auðlindarentu“ eða „,auðlindaarði“, ${ }^{3}$ og peirri orðanotkun fylgir að gefið er í skyn að verðmætin hafi á einhvern (óútskýrðan) hátt orðið til fyrir tilverknað auðlindarinnar en ekki útgerðarfyrirtækja. ${ }^{4}$ Af pessari forsendu er dregin sú ályktun (með rökum sem helst virðast siðferðilegs eðlis) að par með beri að gera auðlindarentuna upptæka í ríkssjóð, og stundum er að auki fullyrt að skattlagning á pessari svokölluðu auðlindarentu hafi ekki áhrif á ganginn í hagkerfinu. ${ }^{5}$

Raunveruleikinn er auðvitað sá að verðmæti verða ekki til nema fyrir mannlegan tilverknað. Náttúruauðlindir geta auðvitað auðveldað sköpun verðmæta, en pær nægja ekki einar sér til pess. Ef einhverjir vilja í alvöru halda pví fram að núverandi arður af íslenskum fiskveiðum stafi af fiskistofnunum verða peir jafnframt a útskýra hvers vegna pessir sömu fiskistofnar sköpuðu ekki auðlindarð áður fyrr (t.d. upp úr 1950 eða jafnvel 1980 fyrir daga kvótakerfisins) pegar peir voru stærri en í dag. Útskýring arðsins mun verða að nefna atriði, eins og tilkomu kvótakerfisins og aðra pætti sem hafa ekki beint með auðlindina sjálfa að gera. Раð afsannar í raun að núverandi arðsemi fiskveiðanna hafi orðið til fyrir tilverknað sjávarauðlindarinnar. ${ }^{6}$

Раð er pví full ástæða til að umræða eigi sér stað um pessi helstu hugtök og kenningar sem að baki peim búa. Petta á sérstaklega við hugtökin rentu og hagnað. Markmiðið hér er að freista pess að varpa ljósi á pað hagræna samhengi sem skapar arð í fiskveiðum og skýra í leiðinni pau hugtök sem par koma eða geta komið við sögu. Par sem hugtakið renta eða auðlindarenta hefur svo mjög verið notað, og stundum misnotað, í pessu sambandi er fyrsta kafla ritgerðarinnar varið í að rekja stuttlega sögu hugtaksins, pann fjölbreytilega skilning sem fræðimenn hafa lagt í hugtakið og hin ýmsu afbrigði rentu sem skýrgreind hafa verið. Pá er í sama kafla stuttlega fjallað um hagnað og tengsl hans við rentu. Í framhaldi er einnig útskýrt hvers vegna rangt sé að álykta að tilvist svokallaðrar auðlindarentu hafi alfarið með ástand auðlindar að gera eða af aðgerðum stjórnvalda til að takmarka aðgang að auðlind, p.e. að pað myndi tilbúinn skort og af honum leiði auðlindarenta. Eignarréttur er ein mikilvægast forsenda pess að skapa arð af fiskveiðum og raunar auðlindanýtingu yfirleitt, að nægjanlega sterkur eignarréttur sé til staðar svo unnt sé að forðast svokallaðan „harmleik

\footnotetext{
2 Afkomutölur sjávarútvegsins má finna á vef Hagstofunnar (hagstofa.is), fyrir tímabilið 1997-2010, og í Pjóðhagsstofnun $(1988,1991,1998)$ fyrir eldri tímabil.

${ }^{3}$ Pessi hugtakanotkun getur reyndar verið mjög villandi, pví auðvitað er allur arður eða renta tengd auðlindum, par sem mannfólkið sjálft er auðvitað mikilvægasta auðlindin (sjá Simon, 1981).

${ }^{4}$ Sjá t.d. umfjöllun í „Skattlagning í sjávarútvegi“, greinargerð sem fylgdi Frumvarpi til laga um veiðigjöld, pskj. 1053, 658. mál, 140. Löggjafarping, 2011-2012.

${ }^{5}$ Johnson (1995) og Arnason (2002) eru meðal peirra sem sýna fram á sú fullyrðing standist ekki. Sjá einnig Anderson \& Libecap (2010).

${ }^{6}$ Petta sjónarmið er t.d. áberandi í umfjöllun í „Skattlagning í sjávarútvegi“, greinargerð sem fylgdi Frumvarpi til laga um veiðigjöld, pskj. 1053, 658. mál, 140. Löggjafarping, 2011-2012.
} 
almenninga" (Hardin, 1968). ${ }^{7}$ Að lokum er rökstutt að tilvist auðlindarentu byggir fyrst og fremst á hæfileikum peirra er veljast til að starfa í sjávarútveginum, á hugviti og framtaksemi peirra, og peim hvata sem peir hafa til að hámarka pað virði sem hægt er að búa úr afurðum af nýtingu fiskistofna.

\section{Hvað er renta?}

Hugtakið „renta“, rent á ensku, virðist upphaflega hafa staðið fyrir hverskonar endurgjald. Á miðöldum, allt frá 12. öld, virðist algengasta notkun pessa orðs snúa að leigugjaldi, pó svo merking orðsins sé kannski frekar endurgjald almennt. ${ }^{8}$ Á miðöldum var algengt að jarðir væru leigðar til landbúnaðar, sbr. leigubændur og hjáleigur í íslensku máli, en petta var mjög ríkjandi fyrirkomulag í Evrópu. Hugtakið virðist pví hafa tengst leigu á jarðnæði fremur en öðrum viðskiptum. Sú tenging hugtaksins hefur síðar verið algeng í lögfræði og hagfræði (sjá nánar um sögu hugtaksins í Fetter 1977).

Pegar hagfræðingar 18. og 19. aldar hófu að móta kenningar til að útskýra og greina hagkerfi pess tíma tengdu peir hugtakið einnig við jarðnæði. Nú var hugtakið renta notað til að lýsa hlutdeild landeigenda í pjóðartekjunum. Pjóðartekjurnar voru prískiptar, í laun handa vinnuafli, hagnað (p.m.t. vextir) til handa fjármagninu og loks rentu til landsins. Pessi útfærsla og notkun rentuhugtaksins er iðulega tengd nafni hagfræðingsins David Ricardo, sem skrifaði um pessi efni undir lok Napóleonstríðanna snemma á 19. öld. ${ }^{9}$ Rentan í kenningum Ricardo stafaði af pví að jarðnæði var aðeins nýtanlegt til kornræktunar og var takmarkað. ${ }^{10}$ Rentan var einskonar afgangsstærð í greiningunni. Renta var pað sem afgangs var pegar búið var að greiða laun og hagnað, en pó pannig að heildarrentan í hagkerfinu gat einungis aukist á kostnað hagnaðar. Vinnan skýrði virði og launasjóðurinn var til pess að mynda nokkurn vegin föst stærð (hlutfallslega séð). Pegar fólki fjölgaði purfti meira korn til að brauðfæða раð, sem kallaði á meira og lakara jarðnæði yrði að fara undir ræktun pess. Petta leiddi til pess að leiga á betra jarðnæði hækkaði í verði, hlutfall rentu jókst og verð á korni hækkaði. Pessi kenning Ricardo, með tengingu við mannfjöldakenningu Malthusar, er röksemd á bak við hugtakið "Járnlög launa“ (Iron-law of wages). Hugakið renta, hjá Ricardo, var pannig til komið sem afgangsstærð sem byggði á forsendu um að heildarjarðnæði, sem mögulega mátti nýta til ræktunar korns, var föst stærð og jarðnæði misgott til ræktunar fallið. Ricardo taldi sjálfur að erfitt eða jafnvel ómögulegt væri í raun að aðgreina landrentuna frá tekjum og hagnaði (Ricardo, 1821; Kitterell, 1957).

\footnotetext{
7 Um mikilvægi eignarréttar, sjá Arnason (2000).

8 Í Íslenskri orðabók (3. útg.) segir að nafnorðið renta hafi eftirfarandi merkingu: tekjur, laun, afgjald, vextir (rentufótur, renturenta), ávöxtun og arður (auðlindarenta, fjárrenta, jarðrenta)

${ }_{9}^{9}$ Ricardo var ekki fyrstur hagfræðinga til að ræða rentuhugtakið, pað höfðu m.a. Dudley North gert 1691, frönsku fýsókratarnir upp úr miðri 18. öld, og Adam Smith árið 1776. Pá komu jafnframt nokkrir hagfræðingar sem voru samtíðarmenn Ricardos fram með rentukenningar á sama tíma. Par má nefna m.a. Robert Torrens, Edward West og Thomas Malthus, sem allir birtu ritgerðir um rentukenningar 1815, eins og Ricardo (Blaug, 1985 bls. 77).

${ }^{10}$ Ricardo gerir ráð fyrir að land til landbúnaðar sé til í föstu magni og aðeins nýtanlegt til að ræktunar. Hann fjallar um ræktun korns og má pví nota korn sem samheiti yfir afurðina sem verður til við ræktun landsins. Petta land til ræktunar er annað hvort nýtt til pess eða látið standa ónýtt. Sjá t.d. umfjöllun um Ricardo og kenningar hans í Blaug (1997) og í Ekelund \& Hébert (2007).
} 
Klassísku hagfræðingarnir, en Ricardo telst til pess hóps, einblíndu mikið á að útskýra tekjuskiptingu framleiðslunnar eftir stéttum pjóðfélagsins og kenningar peirra voru eins konar lögmál tekjuskiptingar pessar ólíku hópa. Kenningar klassísku hagfræðinganna um pessi efni höfðu pví tvær hliðar, pó erfitt geti verið að aðgreina pær fyllilega. Annars vegar hina vísindalegu kenningu um lögmál tekjuskiptingar og hins vegar siðferðlegan rökstuðning til að réttlæta tekjuskiptinguna. Báðar hliðar áttu pátt í að móta niðurstöður peirra.

Pegar hugmyndir hagfræðinga til að útskýra virði breyttust og fóru að setja svip sinn á fræðin í lok 19. aldar var hugmyndum Ricardos hvað pað varðar varpað fyrir borð (аð mestu). ${ }^{11}$ Nútíma kenningar um virði byggja á nytsemi gæða en ekki tilkostnaði eða vinnu. Skorturinn skiptir pó líka máli, enda hin hliðin á virði. Рað er pví réttara sagt að hlutfallslegur skortur, eða framboð í hlutfalli við eftirspurn, útskýri virði. Nútíma hugtak um virði gildir um alla framleiðslupætti, engin ástæða er að gera ráð fyrir að mismunandi lögmál gildi um hina ýmsu pætti eða stéttir. Sama lögmálið gildir pví um tekjuskiptingu til allra framleiðslupátta og lögmálið hefur eingöngu vísindalega hlið og hefur ekki pað hlutverk að réttlæta tiltekna tekjudreifingu. Öll verðmyndun í nútíma hagfræði byggir á samspili framboðs og eftirspurnar, eða fórnarkostnaði peirra sem vilja selja og greiðsluvilja peirra sem vilja kaupa. Virði á jaðrinum, skurðpunktur framboðs- og eftirspurnarferla, mótar markaðsverð.

Hugtakið renta á við um tekjur páttanna, allra pátta. Pessar tekjur eru pó stundum nánar aðgreindar í tvo hluta: pann hluta sem kemur til móts við fórnakostnað seljenda, svo sem laun eða leiguverð, og rentuna, en hún lýsir pá peim hluta tekna páttanna sem eru umfram pað sem dugað hefði til að fá seljendur til að láta af hendi gæði sín. ${ }^{12}$ Rentan lýsir pví tekjum (tekjuhluta) umfram fórnarkostnað hjá öllum framleiðslupáttum og reyndar við sölu allra gæða. Stundum eru önnur hugtök notuð í peim tilgangi að lýsa pessum hluta rentu, t.d hugtökin framleiðendaábati og hagnaður. Рó pað tíðkist að nota nokkur hugtök lýsa pví sama, pá parf að gæta að sér par. Hugtökin hafa ekki öll sömu merkingu og lýsa ekki pví sama. ${ }^{13}$

Í uppsláttarriti Palgrave útgáfunnar um hagfræði er fjallað um rentuhugtakið og pað skilgreint sem greiðsla fyrir notkun auðlindar, hvort heldur auðlindin er fólgin í landi, vinnumönnum, tækjum, hugmyndum eða jafnvel peningum (sjá Alchian, 1991). Síðan er útlistað hvernig við reynum að aðgreina notkun okkar á hugtakinu pegar rætt er um greiðslur fyrir tilteknar auðlindir, sbr. laun, höfundarlaun, leigu (rentu), vexti, o.s.frv. Par er sagan rifjuð upp stuttlega og vísað í notkun Ricardos á hugtakinu en einnig mismunandi

\footnotetext{
${ }^{11}$ Prátt fyrir að notkun á rentuhugtakinu sé stundum ennpá tengd nafni Ricardo pá er með pví ekki verið að vísa til kenningar hans um rentu. Tvær megin ástæður eru fyrir pví að nútíma notkun á rentuhugtaki eru tengdar nafni Ricardo. Annars vegar er verið að vísa í hugmynd um misgæði framleiðslupáttar, sbr. hugmynd Ricardo um misgott land. Hins vegar er verið að vísa í hugmynd hans um að framboð auðlindar eða framleiðslupáttar geti verið (tímabundið) faststett.

${ }^{12}$ Greiðslu (payment) til páttar er pannig skipt upp í tilfærsluhluta (transfer earnings) og rentu (economic rent). Athugið að hin raunverulega greiðsla til páttar samanstendur af hvoru tveggja. Tvísskiptingin felst í aðreina pað sem páttur hefði fengið annars staðar, eða pað sem „nauðsynlegt“ er til að halda pætti í atvinnugrein, og pví sem er pá umfram pað, rentuhlutinn.

${ }^{13}$ Einhver, en pó mismikil, umfjöllun um próun kenninga um tekjuskiptingu (dreifingar) er í flestum kennslubókum um sögu hagfræðikenninga, sjá t.d. Blaug (1997), Landreth \& Colander (2002), Rima (2009), Ekelund \& Hébert (2007), Schumpeter (1954) og Screpanti og Zamgni (2005).
} 
útfærslur og notkun hugtaksins frá peim tíma, og sérstaklega minnst á Alfred Marshall. Par er fyrst nefnt hugtakið „economic rent" eða hagræn renta og "quasi-rent", sem á við greiðslur til auðlinda sem eru fastsettar til skamms tíma eða á greiningartímabili. Petta er stundum íslenskað sem aðstöðurenta (pó ekki megi tengja pað við kenninguna um rentusókn). Í nútíma hagfræði er ekki gert ráð fyrir að neinar auðlindir séu fastsettar til lengri tíma. Tengt pessu eru hugtök yfir sampætta aðstöðurentu (composite quasi-rent, appropriable quasi-rent), en pessi hugtök snúa sérstaklega að aðstæðum samninga um lóðrétta sampættingu eða um sérhæfða framleiðslupætti.

Í ritinu eru einnig nefnd hugtökin Ricardorenta (Ricardo rent) og mismunarenta (differential rent), en bæði eiga hugtökin við um misgæðarentu. Par er verið að vísa til pess að auðlindir geta vera einsleitar til einhverra nota eða misleitar til annarra nota. Ricardo-renta á við pær auðlindir sem eru misleitar til nota hér pó pær séu einsleitar til nota annars staðar. Síðara hugtakið er pá misgæðarenta og vísar til auðlinda sem eru einsleitar til nota hér en eru pó misleitar til nota annars staðar.

Að lokum er síðan fjallað um eða einokunarrentu (monopoly rent), sem stundum er kölluð einokunarhagnaður. Pessi tegund rentu verður til pegar settar eru hömlur á viðskipti með afurðir eða pjónustu og pannig komið í veg fyrir að selja megi pað magn sem spurn er eftir við samkeppnisverð og hagkvæmt er að bjóða.

Á heildina litið pá kemur ekki fram nein skýr skilgreining á hugtakinu í riti Palgrave. Pað sem helst situr eftir við lesturinn er að renta er greiðsla fyrir notkun auðlindar, hvort heldur auðlindin er fólgin í landi, vinnuafli, tækjum, hugmyndum eða jafnvel peningum. Eða, sem sagt, sambærilega merkingu og pað hafði á 12. öld., renta merkir endurgjald.

Pegar flett er í gegnum fræðiútgáfur kemur í ljós að hugtökin renta og hagnaður eru notuð á mjög ólíkan hátt og að auki eru pau oft tengd öðrum hugtökum, og pá ekki alltaf með sama hætti. Pannig má t.d. rekast á eftirfarandi hugtök (ensk heiti peirra vinstra megin og íslenskun til hægri): ${ }^{14}$

$\begin{array}{ll}\text { Rent } & \text { Renta, arður, leiga, greiðsla til pátta } \\ \text { Economic rent } & \text { Hagræn renta } \\ \text { Pure economic rent } & \text { Hrein hagræn renta } \\ \text { Opportunity cost rent } & \text { Fórnarkostnaðarrenta } \\ \text { Inframarginal rent } & \text { Innrijaðarrenta } \\ \text { Monopoly rent } & \text { Einokunarrenta } \\ \text { Managerial rent } & \text { Stjórnunarrenta } \\ \text { Management rent } & \text { Skipulags- eða stjórnunarrenta } \\ \text { Strategic rent } & \text { Renta vegna sérhæfðra pátta } \\ \text { Organizational rent } & \text { Skipulagsrenta } \\ \text { Entrepreneurial rent } & \text { Frumkvöðlarenta } \\ \text { Systematic rent } & \text { Renta vegna sérhæfðra pátta } \\ \text { Temporary rent } & \text { Skammtímarenta } \\ \text { Quasi rent } & \text { Aðstöðurenta, skammtímarenta } \\ \text { Appropriable quasi rent } & \text { Renta vegna sérhæfðra pátta }\end{array}$

\footnotetext{
${ }^{14}$ Umræðu um mörg pessara hugtaka má finna m.a. í Lewin \& Phelan (2002), Lippman \& Rummelt (2003), Matthews (2006), og Trailer (2003), auk Alchian (1991).
} 


$\begin{array}{ll}\text { Resource rent } & \text { (Náttúru)auðlindarenta } \\ \text { Natural resourse rent } & \text { Náttúruauðlindarenta } \\ \text { Scarcity rent } & \text { Skortrenta } \\ \text { Smith'srent } & \text { (Adam) Smith renta } \\ \text { Ricardo rent } & \text { (David) Ricardo renta } \\ \text { Mill's rent } & \text { (John Stuart) Mill renta } \\ \text { Marshall rent } & \text { (Alfred) Marshall renta } \\ \text { Pareto's rent } & \text { (Vilfredo) Pareto renta } \\ \text { Schumpeterian rent } & \text { (Joseph) Schumpeter renta } \\ \text { Hotelling rent } & \text { (Harold )Hotelling renta }\end{array}$

Hér eru talin 25 heiti yfir rentuhugtakið og líklega má finna fleiri. Fjöldi nafngifta segir pó lítt til um hversu margar skilgreiningar tengjast peim, pær gætu hvort heldur verið fleiri eða færri. Sum hugtakanna eiga við almenna skilgreiningu en önnur skilgreina afmarkaðri svið. Nokkur pessara heita eiga rætur að rekja til tiltekinna kenningarsmiða eða skóla sem spruttu af skrifum peirra. Pannig má sjá augljósa tengingu peirra heita sem tengdar eru nafni manna. Önnur möguleg tenging er við eldri og nýrri hagfræði og enn önnur er tengd tilteknum undirsviðum í hagfræði. Flest heitanna hafa nokkrar mismunandi skilgreiningar og eru jafnvel skilgreindar út frá ólíku sjónarhorni. Pannig eru rentuheiti stundum skilgreind út frá sjónarhorni, t.d. pjóðfélags, atvinnugreinar eða fyrirtækis (eða einstaklings), en petta mætti nefna mismundi prep greiningar. Önnur nálgun er út frá teygnihugtakinu og enn ein út frá tímalengd. Einhverjar skilgreiningar nota samhliða teygni, tíma og prep.

\section{Hvað er hagnaður?}

Einhver pessara rentuheita virðast eiga að lýsa eða koma í stað hagnaðarhugtaka, og virðast ýmsar ástæður liggja par að baki, stundum óljósar. Рað er pví líka athyglivert að pegar fræðiritin eru skoðuð pá kemur í ljós að hugtökin um hagnað eru einnig mörg og fjölbreytt, en pó færri en rentuhugtaka (ensk heiti peirra vinstra megin og íslenskun til hægri):

$\begin{array}{ll}\text { Profit } & \text { Hagnaður } \\ \text { Economic profit } & \text { Hagrænn hagnaður } \\ \text { Accounting profit } & \text { Bókhaldslegur hagnaður }_{\text {Normal profit }}{ }^{\text {"Normal“ hagnaður }} \\ \text { Ordinary profit } & \text { Eðlilegur hagnaður } \\ \text { Monopoly profit } & \text { Einokunarhagnaður } \\ \text { Oligopoly profit } & \text { Fákeppnishagnaður } \\ \text { Entrepreneurial profit } & \text { Frumkvöðlahagnaður } \\ \text { Schumpeterian profit } & \text { (Joseph) Schumpeter hagnaður } \\ \text { Knightian profits } & \text { (Frank) Knight hagnaður }\end{array}$

Heiti hagnaðarhugtaka hér upptalin eru 10, en líklega má finna fleiri. Pessi minni fjöldi nafngifta segir pó ekki allt um hversu margar skilgreiningar tengjast peim, skilgreingarnar gætu allt eins verið fleiri eða færri eins og rentuhugtökin varðar. Sum hugtakanna eiga við almenna skilgreiningu en önnur hafa afmarkaðri skilgreiningu, snúa t.d að markaðsformi. Rætur tveggja hugtaka hér má rekja til kenninga peirra hugsuða sem pau eru kennd við og 
prjú hugtakanna tengjast frumkvöðlahagnaði pó pau eigi ekki annað sameiginlegt hvað skilgreiningar varðar.

Í kenningum í nútímahagfræði, sem oft eru kenndar við nýklassík, er ekki gert ráð fyrir hagrænum hagnaði. Í langtíma samkeppnisjafnvægi hafa fyrirtæki engan hagnað, verð er jafnt meðalkostnaði, og framleitt er við lágmarksgildi U-laga meðalkostnaðarfalls. Framleiðsluverðmæti skiptist að fullu á milli framleiðslupáttanna í samræmi við jaðarframleiðnikenninguna. Pví er pó oftast skeytt við, sem einskonar sísönnu, að pessi nálgun komi ekki í veg fyrir að í pessari niðurstöðu sé fólgin „normal“ hagnaður. Ekkert í kenningunni sýnir pó fram á stærð eða umfang pess hagnaðar. Algeng "túlkun“ er hins vegar að segja að í pessu felist einhver „eðlileg“ ávöxtun bundins fjármagns, s.s. eins og ávöxtun fjármagns og á eigið fé fyrirtækjanna, eða pað sem flokka mætti sem fórnarkostnað fjármagns og eigenda. ${ }^{15}$ Pannig er eðlilegur hagnaður talinn til kostnaðarliða í líkaninu og hagnaður umfram pá stærð nefnist pá hagrænn hagnaður, sem er pá hagnaður umfram allan fórnarkostnað. En pað er eins með hugtakið hagrænn hagnaður og með hagnað, að vöntun er á kenningu um hann innan nýklassíska líkansins. Ýmsir fræðimenn hafa í gegnum tíðina sett fram hugmyndir eða kenningar sem rökstyðja hagnað út frá starfsemi frumkvöðla, t.d. Knight og Schumpeter. ${ }^{16}$ Kenningar um hagnað eða rentu frumkvöðla byggja oft á áhættu og óvissu, en í líkani fullkominnar samkeppni er einmitt engin áhætta né óvissa til staðar. Pessar frumkvöðlahugmyndir hafa hins vega ekki náð almennri athygli hagfræðinga og er líklegusta skýring á pví að finna í að pær eru ekki taldar vera fullmótaðar kenningar og að sem viðbót pá passa pær ekki vel inn í líkön nútíma hagfræði. Í uppsláttarriti Palgrave útgáfunnar er einnig að finna kafla með titlinum „Hagnaður og hagnaðarkenning“ (Desai, 2008) par sem fjallað er um hugtakið og kenningar pví tengdu. Niðurstaða peirrar umræðu er, að í hagfræði sé enn vöntun á fullnægjandi kenningu um hagnað í hagfræði. ${ }^{17}$

\section{Hvað er ábati?}

Til viðbótar hugtökunum um hagnað og rentu eru síðan hugtök sem snúa að hreinum ábata sem seljendur og kaupendur hafa af viðskiptum og starfsemi sinni. Yfirleitt er fjallað um heildarábata pjóðfélags, en hann má aðskilja í ábata seljenda og kaupenda, eða framleiðendaábata (producer surplus) og neytendaábata (consumer surplus). Í raun er petta pó nokkuð flóknara pví með ábata seljenda og kaupenda er ekki einvörðungu verið að horfa til smásölufyrirtækja og neytenda neyslugæða. Hér er einnig verið að horfa til seljenda pjónustu framleiðslupátta, t.d. eigenda vinnuafls, fjármagns, eða annarra auðlinda, og ábata kaupenda (demanders surplus) pjónustu pessar sömu framleiðslupátta.

Að auki er síðan ákveðin tenging eða samspil milli pessara síðastnefndu ábatahugtaka og hugtaka um hagnað og rentu. Pannig væri hægt að útskýra ákveðna samsetningu

\footnotetext{
15 „Eðlilegur“ eða „normal“ hagnaður hefur hér eingöngu hagfræðilega merkingu, hér er ekki verið að rökstyðja sanngirni eða réttlæti hagnaðar.

${ }^{16}$ Hér mætti nefna fleiri til sögunnar sem fjallað hafa sérstaklega um frumkvöðla í kenningum sínum, t.d. Richard Cantillon (1680-1734), Jean-Babtiste Say (1767-1832), Carl Menger (1840-1921), Ludwig von Mises (1881-1973) og Israel M Kirzner (f. 1930), pó rentu og hagnaðarhugtök hafi ekki náð að tengjast nöfnum peirra sérstaklega.

17 Í Desai (2008) er pó vikið að pví að margskonar kenningar um hagnað séu til. Vandinn er hins vegar að engin almenn kenning er til eða kenning sem rökstudd er með tilvísun í almennt jafnvægi í hagkerfinu.
} 
framleiðenda- og kaupendaábata með viðeigandi hagnaðar og rentuhugtökum. Af pessum sökum virðist stundum sem ýmis ábataheiti, hagnaðarhugtök, og rentuhugtök séu samheiti yfir hluta tekjustreymis einhverra framleiðslupátta. Alla jafnan er slík ályktun röng, hugtökin eru nánast aldrei fyllilega að lýsa pví sama.

Prátt fyrir pað sem á undan segir um lítt eða illa skilgreind hugtök um rentu, hagnað og ábata, pá verður hér á eftir reynt að varpa einhverju ljósi á pessi hugtök eins og pau varða fiskveiðarnar og skipulag peirra.

\section{Harmleikur almenninga}

Hefðbundin greining á „harmleik fiskveiða“, p.e. fiskveiða við opinn aðgang allra að miðunum, er iðulega sett fram með hliðsjón af mynd 1 (Gordon, 1954). Í upphafi, pegar veiðar hefjast, eru fiskistofnar í náttúrulegu jafnvægi og yfirleitt stórir. Afli er mikill á sóknareiningu og útgerðir hafa hagnað (stundum nefnd renta) af fjárfestingu sinni. Рað leiðir til að peir framtakssömustu stækka við sig og fleiri leggja fyrir sig að hefja útgerð. Fjárfesting í fiskiskipum eykst og tilheyrandi aukning verður í sókn. Með tímanum hefur pað neikvæð áhrif á fiskistofna, peim tekur að hraka og samtímis minnkar afli á sóknareiningu. Smám saman hverfur hagnaðurinn af veiðunum og stærð fiskistofns er pá yfirleitt komin langt undir pá stærð sem gefur af sér mestan afla til lengri tíma, svokallaðan hámarks jafnstöðuafla. Vandinn við opinn aðgang að fiskveiðum er, að svo lengi sem tekjur eru umfram kostnað munu útgerðir vera fúsar til að fjárfesta í fiskveiðum og pessi hvati til fjárfestinga hverfur ekki fyrr en hagrænn hagnaður hverfur. Við pað jafnvægi er enginn frekari hvati til fjárfestinga, en pað næst ekki jafnvægi fyrr en stofninn hefur minnkað pað mikið að heildarkostnaður við veiðarnar er orðinn jafn heildartekjum og hagnaður (rentan) hverfur.

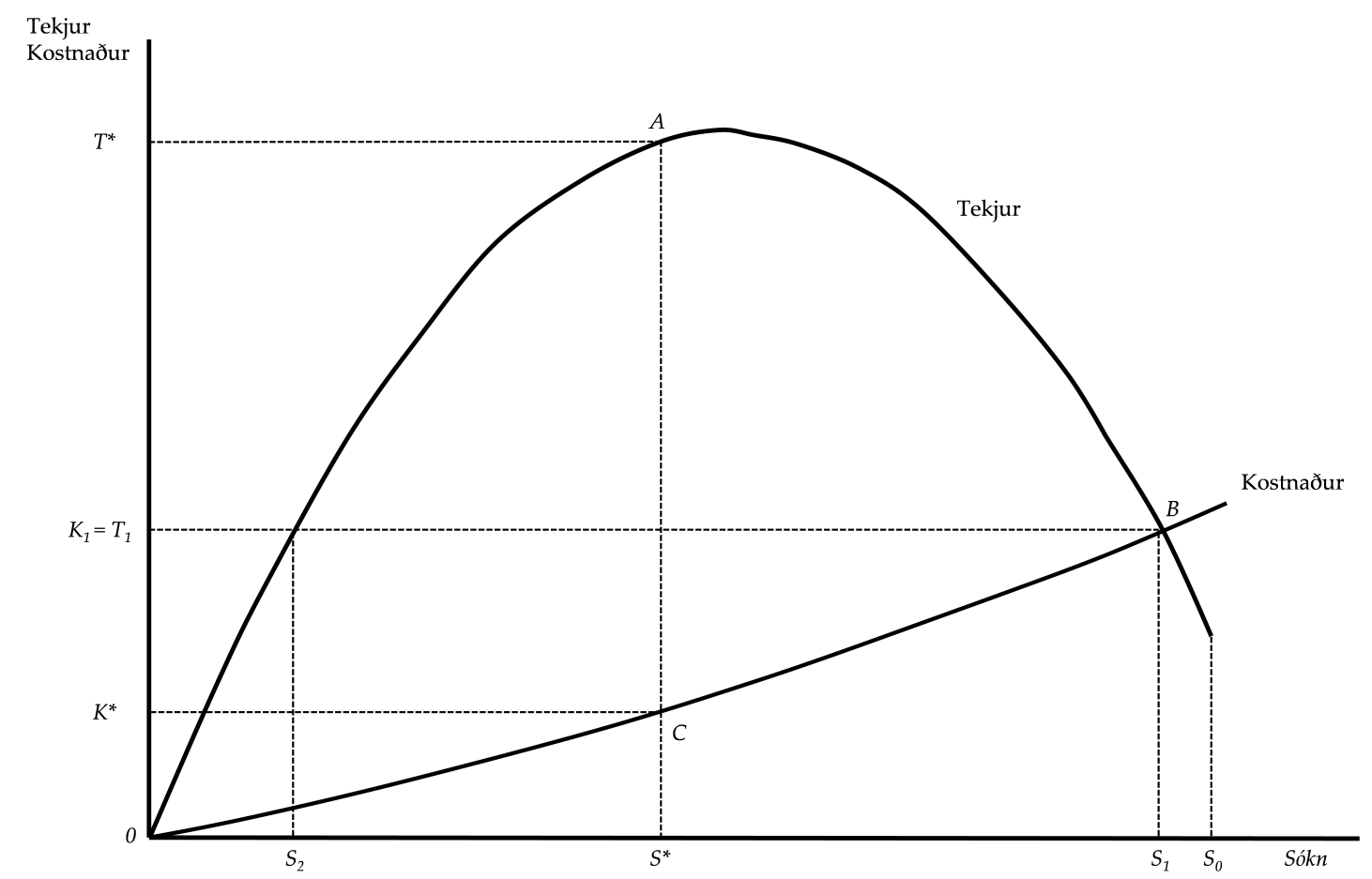

Mynd 1. Hefðbundið líkan hagfræðinnar um fiskveiðar 
Á mynd 1 er sókn mæld út eftir lárétta ásnum en tekjur og kostnaður eftir lóðrétta ásnum. Neðri ferillinn á myndinni (sá upphallandi) sýnir kostnað og er gert ráð fyrir að hann aukist samhliða sókninni. Efri ferillinn á myndinni (sá hvelfdi) sýnir aftur á móti tekjur sem hér eru skilgreindar sem virði jafnstöðuafla, pað er sá afli sem taka má til langframa úr fiskistofni án pess að stofninn minnki eða vaxi. ${ }^{18}$

Á myndinni vaxa tekjur hratt fyrst í stað pegar veiðar eru litlar en kostnaður mun hægar. Við meiri sókn ná tekjur hámarki og falla síðan en kostnaður heldur áfram að vaxa. Hagnaður er hámarkaður par sem bilið á milli tekna- og kostnaðarferlanna er mest, eða í punkti A (eða sókninni $S^{*}$ ), sem samsvarar fjarlægðinni AC. Ef sóknin er meiri leiðir pað til pess að hagnaður minnkar. Í punkti B eru heildartekjur jafnar heildarkostnaði og enginn hagnaður af veiðunum. Pessi punktur (B) samsvarar pví jafnvægi sem mun verða við opinn aðgang fiskveiða. Sókn umfram pennan punkt (eða $S_{1}$ ) er ekki fýsilegur kostur, par er kostnaður meiri en tekjur eða tap á veiðum. Minni sókn, á milli A og B, skapar hins vegar enn hvata fyrir aðila að hefja útgerð og sókn.

Opinn aðgangur að veiðunum hvetur pannig til mikillar sóunar, sem kemur ekki eingöngu fram í pví að gengið sé of nærri fiskistofnum og óhagkvæmri fjárfestingu og notkun skipa og búnaðar. Til viðbótar er hætt við, og pað sýnir reynslan, að kappið í aflamagn verður svo mikið að pað bitnar á gæðum fiskafla og leiðir pannig til verðminni fiskafla og fiskafurða. ${ }^{19}$ Hinni svokölluðu „,auðlindarentu“ (eða hagnaði) er pannig sóað að mestu eða alveg.

\section{Eignarréttur byggir ekki á einokun}

Hér er líka ástæða til að útskýra pað sem stundum virðist valda misskilningi um eignarrétt og mikilvægi hans. Eignarrétturinn hámarkar rentu vegna peirra hvata sem hann gefur til að aðilar hámarki virði auðlinda sem peir hafa eignarrétt til. Rentan sem verður til við hvata eignarréttar er ekki tilkomin vegna tilbúins skorts eða takmarkanna á viðskiptum. Hún byggir á að skilgreint er hver beri ábyrgð á og ráði notkun auðlinda, og nýti pannig auðlind á skilvirkan hátt og eigi í framhaldi tilkall til afraksturs hennar. ${ }^{20}$

Á yfirborðinu kann að virðast sem hámörkun nettó virðis auðlindar með takmörkun á notkun hennar, annars vegnar, og takmörkun einokunar á afurðarmagni undir pví magni sem væri við meiri samkeppni, hins vegar, séu af sama toga. Og í framhaldi, ef takmarkanir einokunar teljast skaðlegar hagkerfinu af hverju gildir pá ekki hið sama pegar umbreytt er frá skipulagi opins aðgangs að nýtingu auðlinda í skipulag aðgangstakmarkanna, p.e. frá

\footnotetext{
${ }^{18}$ Sýna má fram á að til sérhverrar stofnstærðar svari einn ákveðinn jafnstöðuafli sem nemur vexti fiskistofnsins við pá stofnstærð. Gera má ráð fyrir að samhengi sóknar og stofnstærðar í jafnstöðu sé pannig að pví meiri sem sóknin er pví minni verður jafnstöðustofnstærðin. Jafnstöðuaflinn, sem í raun endurspeglar vaxtargetu stofnsins, er breytilegur eftir stofnstærðinni. Ef sóknin fer umfram ákveðið hámark og haldið umfram pau mörk til lengri tíma eyðist stofninn. Ofveiði stofnsins niður fyrir eitthvert pröskuldsgildi getur pannig leitt til að hann nái ekki að stækka aftur að ráði prátt fyrir að beinni sókn í hann sé hætt. Hins vegar ef engin sókn er, og p.a.l. engin veiði pá ætti stofninn að vera í náttúrulegri stofnstærð. Parna í milli má finna jafnstöðustofnstærð og skýrir pað hvelfdan feril virðis afla á mynd 1 .

${ }^{19}$ Sjá líka Homans \& Wilen (2005), Herrmann (1996) og Herrmann \& Criddle (2006).

${ }^{20}$ Hversu sterk, eða fullkomin, eignarréttindi eru hefur auðvitað áhrif hér. Aflahlutdeildir í fiskveiðum Íslendinga, kvótarnir, eru hagfræðlega séð framseljanleg nýtingarréttindi og pví jafnframt eignarréttindi, pó ófullkomin séu. Sjá nánar í Arnason (2000).
} 
skipulagi sameignar í skipulag séreignar? Pví er til að svara að á pessu er reginmunur. Vandinn sem bent er á sem fylgifisks einokunar er að afurðamagn er minna en pað sem skilvirkt væri, á meðan að opinn aðgangur leiðir til afurðamagns sem er meira en pað sem skilvirkt væri.

Petta má sjá betur á myndinni hér að neðan (mynd 2). Myndin er í grunninn mynd af einokun á markaði hefðbundinna vara, en á ekki sérstaklega við fiskveiðar enda aðeins notuð hér til að útskýra hvernig bæði einokun og ytri-áhrif leiða til frávika frá hagkvæmu jafnvægi. Við aðstæður samkeppni pá myndi jafnvægi myndast við skurðpunkt markaðseftirspurnar og markaðsframboðs við $c$, sem hér er sýnt sem efri upphallandi ferillin merktur jaðarkostnaður. Pessi jaðarkostnaðarferill sem hér er sýndir væri pá í raun summa framboðsferla allra samkeppnisfyrirtækjanna, en peir byggja á jaðarkostnaðarferlum fyrirtækjanna. Samkeppnisjafnvægi væri pví við skurðpunkt eftirspurnar og jaðarkostnaðar á myndinni, par sem lesa má samkeppnisverð á lóðrétta ásnum og magnið $S$ peim lárétta. ${ }^{21}$

Ef aðeins eitt fyrirtæki starfar sem einokun á pessum markaði pá takmarkar pað afurðamagnið við $E$ í peim tilgangi að hækka verð upp í einokunarverð. Við pessa takmörkun afurðamagns við $E$, sem er minna magn en $S$, pá verður til svokallað velferðartap (deadweight loss) einokunar, sem lýst er með príhyrningi sem afmarkast af bcd á myndinni. Við pessa takmörkun verður einokunarhagnaðurinn, eða einokunarrentan, rétthyrningur sem afmarkast af ghd-einokunarverð.

Vandi opins aðgangs, eða sameignarvandinn („harmleikur almenninga“) eins og hann er oftast nefndur, getur birst í of miklu afurðamagni (og of miklu magni aðfanga). Pannig getur verið um of mikinn fjölda veiðiskipa að ræða sem jafnframt veiða umfram pað magn sem skilvirkast væri. Petta er pað ástand sem myndin gefur til kynna sem vanda opins aðgangs, eða pess sem oft er nefnt vöntun eignarréttinda.

\footnotetext{
${ }^{21}$ Athugið að mynd 2 er frábrugðin öðrum myndum hér í pví að á lárétta ásnum er afurðamagn (aflamagn) í stað sóknar á öðrum myndum. Fyrir fiskveiðar merkir S pví hagkvæmt aflamagn en á mynd 1 var $S^{*}$ hagkvæm sókn, en hvort tveggja byggir auðvitað á hinu. Hér horfum við framhjá pví hvernig hakvæmt magn yrði ákvarðað í raun fyrir fiskveiðar.
} 


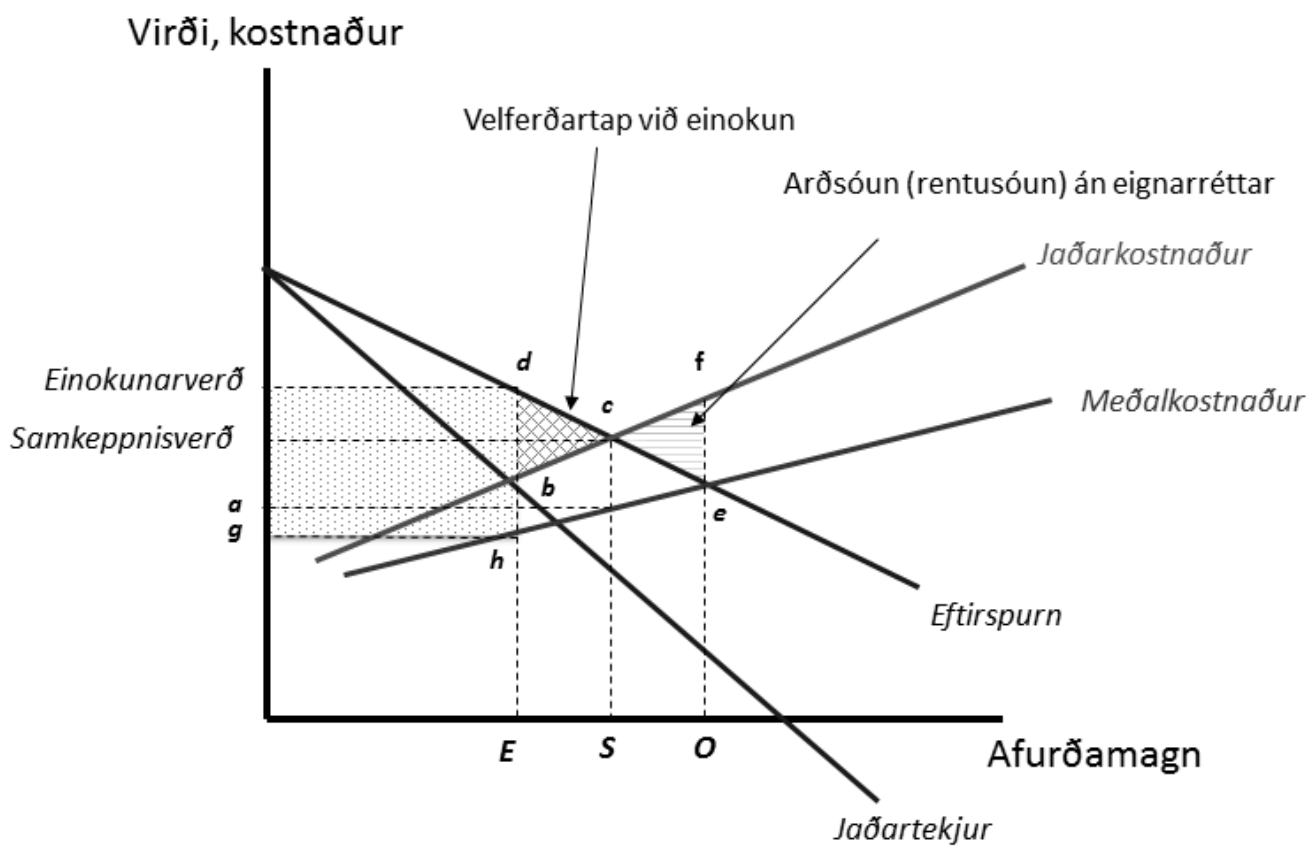

Mynd 2. Eignarréttur og einokun er sitthvort ${ }^{22}$

Í stað pess að aðeins væri sótt magnið $S$, sem er samkeppnismagnið, með viðeigandi fjölda veiðiskipa, pá er sótt umfram pað og í magnið merkt $O$ á myndinni. Við opinn aðgang pá purfa útgerðir veiðiskipanna ekki að taka tillit til kosnaðar sem lendir á öðrum útgerðum og pá hafa pær ekki hvata til að horfa til pess hvaða áhrif ofveiði hefur á framtíð fiskistofnanna (sem er pá jafnframt kostnaður sem horft er framhjá). Ferillinn á myndinni sem merktur er meðalkostnaður, neðri upphallandi ferilinn, sýnir pví framboðsferil fyrirtækjanna við opinn aðgang. Príhyrnda svæðið sem markast af cef sýnir pá rentusóunina við opinn aðgang. Breytt skipulag við nýtingu, takmörkun aðgangs í stað opins aðgang, gæti hins vegar haft áhrif í átt til pess að útgerðir tækju tillit til pessa ytri kostnaðar. Eignarréttur útgerða, kerfi aflahlutdeilda, er pannig dæmi um skipulag sem getur orðið til pess að tekið er tillit rétt mats á fórnarkostnaði og pá væri framboðsferill fyrirtækjanna lýst með jaðarkostnaðarferlinum í stað meðalkostnaðarferilsins, og pær myndu pá hámarka við skurðpunkt eftirspurnar og framboðsferilsins við eignarrétt, sem er pá við magnið $C$ og samkeppnisverðið.

\section{Einsleit eða misleit fyrirtæki?}

Í hefðbundinni nálgun hagfræðinnar, eins og peirri hér á undan, er gert ráð fyrir að fyrirtæki; stjórnendur, starfsmenn og fjármunir pess, séu einsleit (homogeneous), p.e. að allir pessara hafi sömu hæfni, kunnáttu, pekkingu, getu, afköst, o.s.frv., til framleiðslu í atvinnugrein. Pegar svo er pá eru allir í raun eins og ekki skiptir máli hver peirra starfar í greininni og hver ekki, enda yrði afkoma allra sú sama innan greinarinnar. Pegar svo er gilda sömu jaðarkostnaðarferlar og meðalkostnaðarferlar fyrir alla, p.e. ferlar eru nákvæmlega eins hjá öllum í atvinnugreininni. Efnahagsleg afkoma meðalbátsins er pví jöfn afkomu allra báta, og par með jaðarbátsins. Ef við pessar aðstæður kæmi í ljós að til staðar væri hagrænn hagnaður,

\footnotetext{
${ }^{22}$ Mynd pessi byggir á Anderson \& McChesney (2003, bls. 67), en í pví ritgerðasafni er jafnframt að finna margar lærðar ritgerðir um hagfræði eignarréttinda.
} 
p.e. hagnaður umfram pað sem nefnt er „normal“ hagnaður, pá benti pað til pess að svokölluð „auðlindarenta“ væri til staðar. ${ }^{23}$

Raunhæfari nálgun er að taka tillit til pess að pannig er petta ekki í raun. Fyrirtæki og allt peim viðkomandi eru mjög misleit: Skipakostur ólíkur, uppbygging fyrirtækja önnur, aldur og reynsla stjórnenda og starfsfólks breytileg, pekking er sérhæfð, áhættusjónarmið ólík, o.fl. pettað hefur í för með sér að kostnaður, bæði jaðar- og meðalkostnaður, væri ólíkur milli fyrirtækja. Раð leiðir einnig til pess að tilvist hagræns hagnaðar er ekki einhlítt merki um tilvist auðlindarentu pó pað sé hins vegar merki um rentu engu að síður. Í fiskveiðum sem búa við opinn aðgang gæti einstakt veiðiskip haft hagrænan hagnað umfram „normal“ hagnað vegna aukinnar hagkvæmni. Einnig gæti tiltekið veiðiskip haft eingöngu eðlilegan hagnað eða neikvæðan hagnað (tap) vegna minni hagkvæmni eða skorts á hagkvæmni. Eða m.ö.o. ef veiðiskipin eða útgerðir eru ekki einsleitar (homogenous), en eru pess í stað sundurleitar (heterogenous), pá er öll skírskotun til meðalskipsins aðeins skírskotun til meðaltals dreifingarinnar í afkomu allra bátanna. Meðalbáturinn er pá ekki lengur jafngildur jaðarbátnum. ${ }^{24}$

Petta má sjá betur á mynd $3 .{ }^{25}$ Á henni er gert ráð fyrir fiskveiðum með opnum aðgangi og sundurleitum flota $n$ skipa. Jafnframt er forsenda um að petta sé samkeppnisgrein og að útgerðir hafi pví ekki áhrif á markaðsverð afla, að pær séu verðpegar. Jaðartekjur (ferlar) allra útgerða eru pví pær sömu og jafngilda meðaltekjum greinarinnar. Hver bátur hámarkar afkomu sína við pað magn sóknar sem jafnar saman jaðarkostnaði og jaðartekjum skipsins. ${ }^{26}$ Veiðiskipin eru aðgreind með mismunandi kostnaðarferlum, p.e. meðalkostnaðarferlar peirra liggja í mismunandi hæð á myndunum. Vænta má pess að útvegurinn sé fremur í ójafnvægi en jafnvægi, par sem sumir bátar hafa jákvæða afkomu en aðrir neikvæða, p.e. sumir hafa hagrænan hagnað en aðrir eru í tapi. Par sem að sumir bátarnir eru með neikvæða afkomu á einhverju tilteknu ári pá má gera ráð fyrir að heildarsókn útvegsins sé umfram jafnvægissókn fiskveiða við opinn aðgang.

\footnotetext{
${ }^{23}$ Í reynd er hugtakið „,auðlindarenta“ notað til að lýsa hagrænum hagnaði eða hluta hans.

${ }^{24}$ Hér á eftir er að öðru leyti byggt á hefðbundnum forsendum nútíma rekstrarhagfræði. Pannig eru ferlar fyrir kostnað og tekjur hefðbundnir, og sé jafnræði milli heildar peirra, að pá sé enginn hagrænn hagnaður til staðar en engu að síður „normal“ hagnaður, p.e. ávöxtun á bundið fjármagn. Petta eru almennar forsendur samkeppnislíkansins.

${ }^{25}$ Hér er byggt verulega á Coglan \& Pascoe (1999) og Anderson (1989). Sjá líka Johnson \& Libecap (1982).

${ }^{26}$ Jaðarkostnaðarferlar á myndunum hér lýsa langtíma jaðarkostnaði. Pannig er gert ráð fyrir að inni í peim kostnaði sé fórnarkostnaður fjármagns, p.e. raunafskriftir og ávöxtun fjármagns.
} 
(a) Skip k međ hagnað

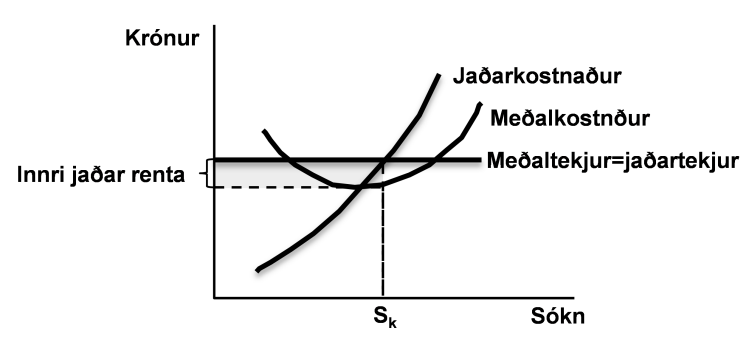

(c) Skip n með tapi

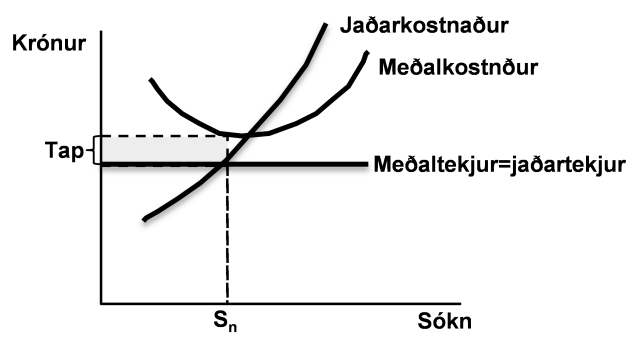

(b) Skip $m$ á núlli

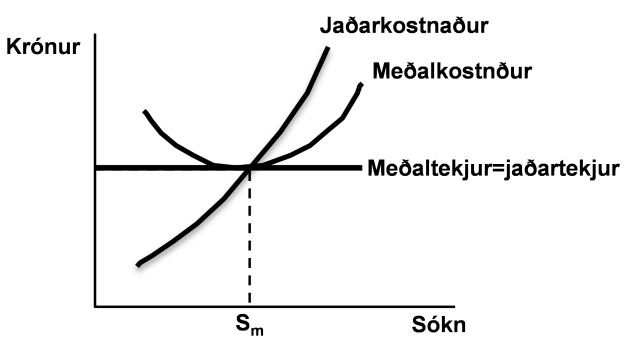

Fiskveiðar í heild

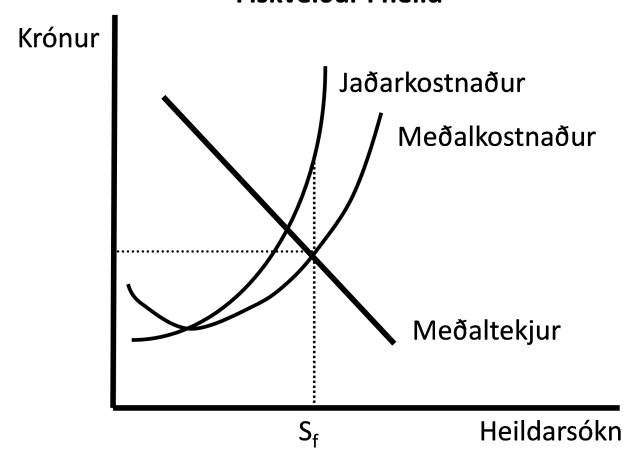

Mynd 3. Opnar fiskveiðar, misleit veiðiskip ${ }^{27}$

Á mynd 3 má sjá að afkoman hjá Skipi $k$ er jákvæð, við skurðpunkt jaðartekna og jaðarkostnaðar eru meðaltekjur nokkru hærri en meðalkostnaður, og pað er pá hagrænn hagnaður. Skip $m$ er með normal hagnað, meðaltekjur eru jafnar meðalkostnaði, eða enginn hagrænn hagnaður. Skip $n$ er hins vegar með neikvæða afkomu, meðaltekjur eru lægri en meðalkostnaður, eða hagrænt tap. Fyrirtæki eða skip í stöðu skips $n$, með tap, eru hér sögð utanjaðar, en pau með hagrænan hagnað, eins og skip $k$, eru innanjaðar. Einnig má lýsa pessu með hugtökunum utanjaðarrenta (tap) og innrijaðarrenta (hagnaður). ${ }^{28}$ Svo framarlega sem $m-1>n-m$, p.e. fleiri skip eru innan jaðars en utan jaðars, pá má gera ráð fyrir að meðalafkoman í veiðunum sé jákvæð. ${ }^{29} \mathrm{Ef}$ taprekstur sumra skipanna væri viðvarandi pá mætti búast við pví að til lengri tíma litið myndi skip $n$ hætta veiðum. En jafnframt, ef skip $k$ er rekið að jafnaði með hagnaði pá skapar pað hvata fyrir viðbótarskip að hefja veiðar. Hugsanlegt er pví að tilvist hagnaðar og taps með pessum hætti leiði til pess að ekkert langtímajafnvægi myndist í veiðunum. ${ }^{30}$

Hefðbundin niðurstaða í greiningu á líkani opinna fiskveiða er að par myndist langtímajafnvægi par sem rentan, eða auðlindarentan eins og hún er oft nefnd, sé uppurinn. Í greiningunni hér, sem styðst við forsendu um sundurleita (heterogeneous) í stað einsleitra (homogeneous) framleiðslupátta, er niðurstaðan ekki sú að rentan sé einfaldlega uppurin

\footnotetext{
27 Mynd pessi byggir á Coglan \& Pascoe, 1999, bls. 221.

${ }^{28}$ Hugtökin innjaðarrenta og utanjaðarrenta eru pýðing á ensku hugtökunum inframarginal rent (intramarginal rent) og extra-marginal rent (extensive marginal rent).

${ }^{29}$ Ef pað eru fleiri skip eins og $k$ heldur en eins og $n$, pá er meðalafkoman jákvæð.

${ }^{30}$ Svo lengi sem tekjur eru hærri en breytilegur kostnaður má gera ráð fyrir að útgerðir haldi áfram rekstri til skemmri tíma, par sem aðrir notkunarmöguleikar fjármuna eru ekki til staðar pá.
} 
heldur að hún sé neikvæð. ${ }^{31}$ Petta má sýna á grafinu á peim hluta myndar 3 sem ber titilinn Fiskveiðar í heild. Sá myndarhluti sýnir afkomu fiskiskipanna í heild (ferlarnir hér eru summa ferla einstakra skipa) og má par sjá að sókn er við skurðpunkt meðaltekna og meðalkostnaðar, sem túlka má sem að jafnaði sé afkoman á núlli. En í peim punkti er jaðarkostnaður hærri en meðaltekjur, sem segir pá að eitt eða fleiri skip séu með neikvæða afkomu og sóun eigi sér stað í fiskveiðunum.

Með breyttu skipulagi veiðanna, fiskveiðstjórnun eins og pað er iðulega nefnt, má mögulega hafa áhrif á pessa niðurstöðu. Fiskveiðstjórnun gæti falist í aðgerðum eða innleiðingu hvata til að draga úr sókn pannig að hún verði minni en við opinn aðgagn. Á mynd 4 er gert ráð fyrir að breytt skipulag hafi dregið úr sókninni niður fyrir pað sem hún væri við opinn aðgang og að petta hafi gerst með pví að minnka fjölda peirra skipa sem stunda veiðarnar, að $x$ fjöldi báta hafi verið fjarlægðir.

Nýja skipulagið byggir pannig á einhverjum takmörkunum aðgangs eða leyfisveitingum, pannig að ný skip geti ekki komið inn í stað peirra sem farin eru. Pessi minnkun í veiðisókn leiðir til pess að meðaltekjur á sókn hækka úr $r$ í $r^{\prime}$. Peir $n-x$ bátar sem nú sækja veiðar starfa við skurðpunkt jaðartekna (sem eru jafnar meðaltekjum í greininni) og jaðarkostnaðar peirra. Par sem meðaltekjur á sóknareiningu hafa aukist hefur pað áhrif til aukinnar sóknar peirra báta sem enn stunda veiðar. Hér hins vegar nær hver og einn bátanna að skila hagnaði og sá sem síst stendur sig, skip $n-x$, var einmitt á jaðrinum með engan hagrænan hagnað pegar $\mathrm{MT}=r$, en er nú með jákvæðan hagrænan hagnað við MT = $r^{\prime}$ (sem skyggðu svæðin sýna). Hin skipin eru nú öll einnig með hagrænan hagnað.

Pennan hagnað er hins vegar ekki hægt að líta á eða túlka í heild sinni sem „auðlindarentu,“ né heldur er heildarrenta endilega jöfn heildarhagnaði. Rentan sem til staðar er nú skiptist í innijaðarrentu og aðra rentu („,auðlindarentu“). Innrijaðarrentan og sá hluti hagnaðar sem að henni snýr byggir einfaldlega á að ekki eru allar útgerðir með sömu hagkvæmni, og pær sem betur standa sig eru með rentu og/eða hagnað umfram hinar. Auðlindarentan og sá hluti hagnaðar sem að henni snýr hér sýnir hagnað lakasta skipsins sem enn er við veiðar eftir tilkomu breytts skipulags eða stjórnunar veiðanna. ${ }^{32}$

\footnotetext{
${ }^{31}$ Pað skal hafa í huga að petta er ein möguleg niðurstaða en alls ekki sú eina. Eins og fyrr segir, pá má ætla að opnar fiskveiðar með sundurleitum páttum einkennist af ástandi ójafnvægis fremur en jafnvægis, p.e. að ekkert langtímajafnvægi myndist.

32 Við fyrra skipulag veiðanna væri litið til pessa sem innrijaðarrentu eingöngu. En við breytt skipulag fiskveiðstjórnunar „umbreytist“ hluti innrijaðarrentu í auðlindarentu (eða skipulagsrentu), eins og er útskýrt hér á eftir. Petta verður að hafa hugfast, sérstaklega ef skattleggja á rentuna (hagnaðinn), enda er sá möguleiki til staðar að skattlagning rentu leiði til pess að afkoma hagkvæmustu útgerða verði pá lakari við breytt skipulag fiskveiðistjórnunar en hún var við fyrra skipulag óheftra veiða. Sjá nánar í Anderson (1989).
} 
(a) Skip $k$

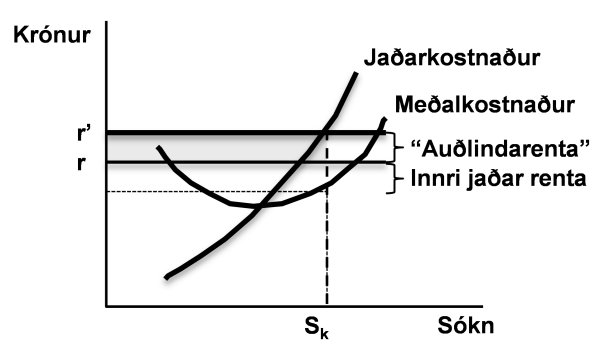

(c) Skip $n-x$

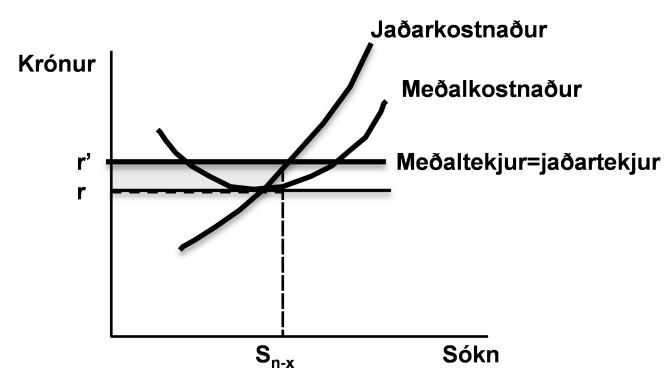

(b) Skip $m$

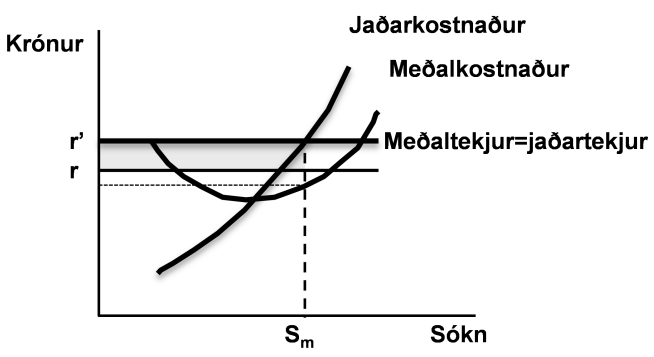

Fiskveiðar í heild

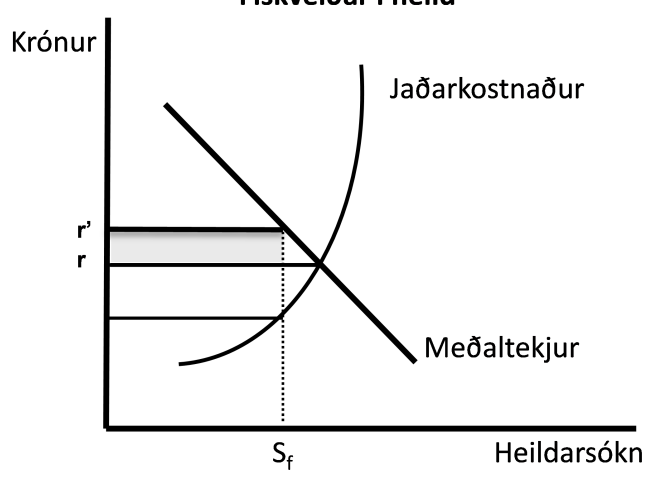

Mynd 4. Áhrif góðs skipulags fiskveiða ${ }^{33}$

Af ofansögðu má ljóst vera að hagrænn hagnaður í fiskveiðum sem byggjast á sundurleitum (heterogeneous) framleiðslupáttum samanstendur af tvennu - innrijaðarrentu og „auðlindarentu.“ Pegar reynt er að aðgreina hagnað sem er umfram „normal“ hagnað pá mun skipting hans velta að miklu leyti á hagnaði jaðarskipsins. Par sem mögulegt er fyrir einhverjar útgerðir að hagnast umfram eðlilegan (normal) hagnað við óheftar veiðar (og opinn aðgang) pá er eingöngu hægt að benda á jákvæða „,auðlindarentu“ pegar jaðarskipið í veiðunum er einnig að hagnast umfram eðlilegan hagnað. Раð аð finna eða benda á jaðarskipið getur að auki verið miklum erfiðleikum bundið.

\section{Áhrif góðs skipulags fiskveiða. Af hverju?}

Hér að ofan var áherslan á að skoða afkomu einstakra útgerða, með dæmum um mismikla hagvæmni skipa. Á mynd 5 er petta skoðað meira út frá afkomunni í greininni allri.

Hér er auðlindarentan skilgreind sem mismunur milli heildarumfangs hagræns hagnaðar og innrijaðarrentu. Myndin skiptist í prjá hluta og sýnir hver hluti niðurstöðu mismundandi útfærslu af breyttu skipulagi fiskveiðistjórnunar. Afleiðingar pessara mismunandi útfærslu skipulagsbreytinga eru nokkuð ólíkar en í öllum tilfellum er gert ráð fyrir að tekist hafi að minnka sókn niður fyrir pað ójafnvægisástand óheftra veiða (með sundurleitum framleiðslupáttum) sem fjallað var um hér að ofan.

\footnotetext{
${ }^{33}$ Mynd pessi byggir á Coglan \& Pascoe, 1999, bls. 222.
} 


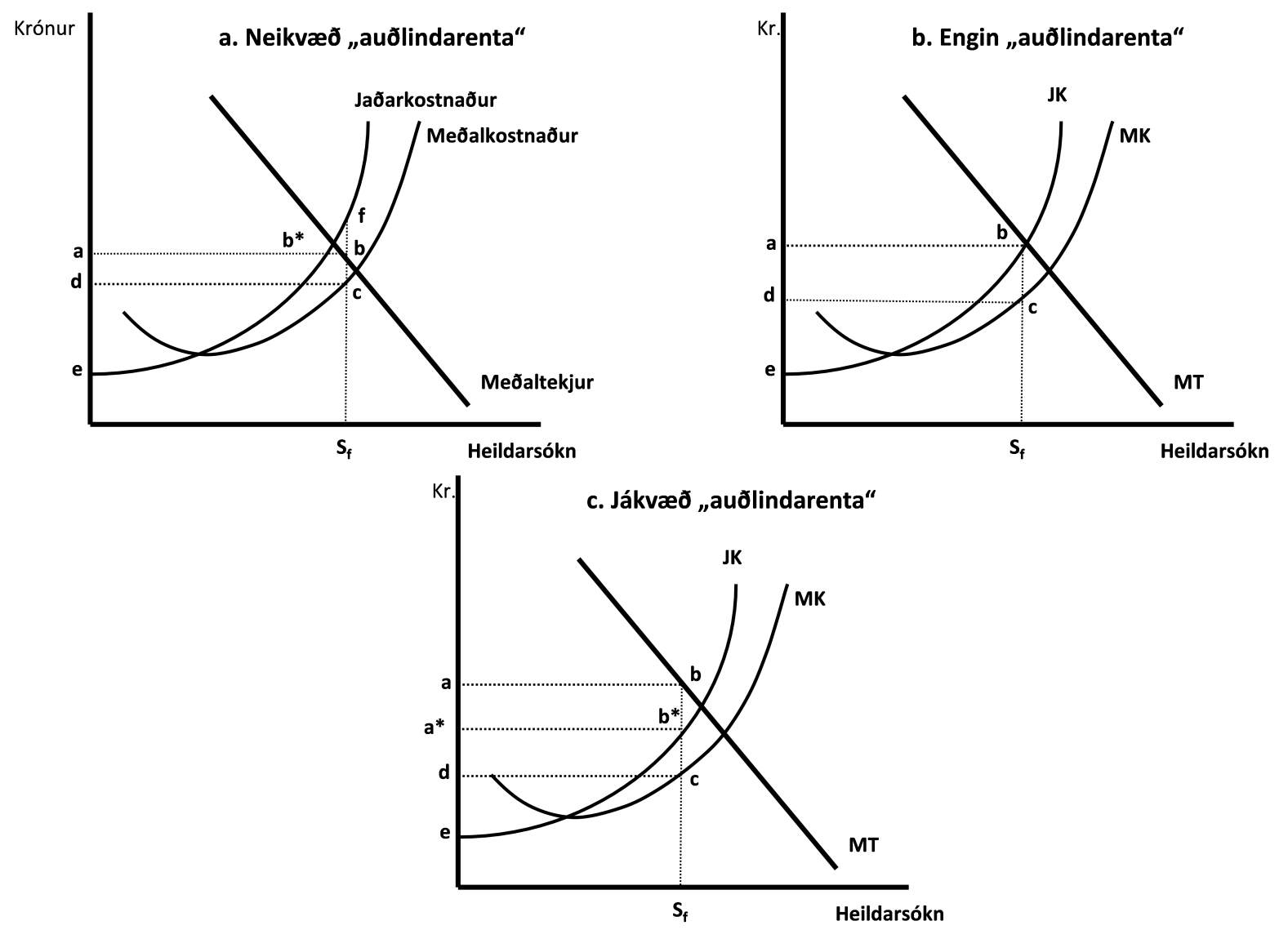

Mynd 5. Áhrif góðs skipulags fiskveiða á hagnað og rentu. ${ }^{34}$

Á myndarhluta 5a er jákvæður hagnaður af veiðunum og er hann sýndur sem svæðið merkt abed. Innrijaðarrentan er sýnd sem svæðið $a b^{*} e$ og er pað svæði stærra en svæði hagræns hagnaðar (abed) og pví er auðlindarenta hér neikvæð, sýnd hér sem jafngildi svæðis $b^{*} b f$. Ástandið er pó skárra hér en pað var við pær óheftu veiðar sem lýst var á mynd 3, auðlindarentan er ekki eins neikvæð nú og áður.

Á myndarhluta $5 \mathrm{~b}$ er hagrænn hagnaður jafnmikill og innrijaðarrentan í fiskveiðunum, pannig að auðlindarentan er pá engin (jafnt og núll). Petta er sambærileg niðurstaða og fæst í líkani um opinn aðgang (með einsleitum framleiðslupáttum), en sú niðurstaða er líkast til óraunhæf nema með (breyttri) fiskveiðistjórnun. ${ }^{35}$

Á myndarhluta 5c er mögulega um jákvæða auðlindarentu að ræða sem afleiðingu breytts skipulags sem leitt hefur til minnkunar í heildarsókn í fiskveiðunum. Hér er heildarhagnaður sýndur sem svæðið abed, en innrijaðarrentan sýnd sem svæðið $a^{*} b^{*} e$. Heildarumfang auðlindarentu væri samkvæmt pessu svæðið $a b b^{*} a^{*}$.

\section{Áhrif á „auðlindarentu“}

Greiningin hér á undan byggir í grunninn á hefðbundnum forsendum nútíma hagfræði, sem kennd er við nýklassík. Ferlar fyrir kostnað og tekjur hefðbundnir, og sé jafnræði milli

\footnotetext{
${ }^{34}$ Mynd pessi byggir á Coglan \& Pascoe (1999, bls. 223).

${ }^{35}$ Opinn aðgangur eða frjálsar veiðar er auðvitað form fiskveiðistjórnunar, eða skipulags, pótt pað verði vart talið árangursríkt fyrirkomulag.
} 
heildar peirra, að pá sé enginn hagrænn hagnaður til staðar en engu að síður „eðlilegur" hagnaður, p.e. ávöxtun á bundið fjármagn. Petta eru í raun almennar forsendur samkeppnislíkansins.

Einni forsendu er pó breytt; í stað einsleitra (homogeneous) fyrirtækja eða framleiðslupátta er gefin forsenda um pau séu misleit (heterogeneous). Sú forsenda leiðir af sér, að jafnvel pó fyrirtækin í heild sinni hafi ekki (nettó) hagrænan hagnað pá geta einstök fyrirtæki haft slíkan hagnað, eða tap. Og reyndar er pað afleiðing pessa við óheftar veiðar, að ef einhver fyrirtæki hafa hagrænan hagnað að pá verða einhver önnur að hafa neikvæðan hagnað, eða tap (eins og sýnt var á mynd 3). ${ }^{36}$ Рað að framleiðslupættir séu misleitir merkir að hæfni eða geta peirra sé ólík og leiðir til pess að sömu tekjur skila mismiklum ábata til páttanna. ${ }^{37}$

Forsenda um misleitni fyrirtækja leiðir jafnframt til pess að hægt er að skilgreina tilvist rentu, en hún byggir á pví að afkoma einstakra fyrirtækja verður ólík. Sum eru pá að hagnast, og hugtakið innrijaðarrenta er oft notað til að lýsa pví, en önnur eru pá í tapi, og er pað nefnt utanjaðarrenta (extra marginal rent). ${ }^{38}$ Ein niðurstaða fyrir atvinnugrein í heild sinni væri að heilarhagnaður væri jafn heildartapi, eða meðalafkoma á núlli, en pað er lýsing sem nota má um mynd 3. Sé heilarhagnaður hins vegar eitthvað meiri en heildartap, pannig að prátt fyrir hagnað (innrijaðarrentu) og tap (utanjaðarrentu) einstakra fyrirtækja, pá sé meðalafkoma jákvæð, og má vísa til myndar 5a sem mögulegar lýsingar á pví. Sé meðalafkoman jákvæð og ekkert fyrirtæki í tapi en einhver á núlli, pá gæti mynd 5b átt par við. Pegar öll fyrirtæki eru með hagnað, en pó mismikinn, og meðalafkoma peirra er pá auðvitað jákvæð, pá má aðgreina rentu í tvo hluta, eins og gert er á mynd 5c. Á peirri mynd 5c er innrijaðarrenta skilgreind neðan við línu sem dregin er milli punkta $a^{*}$ og $b^{*}$ (og neðri mörk hennar er JK ferillinn) og ofan pessarar línu $a^{*} b^{*}$ og upp að línu milli $a$ og $b$ er skilgreind „auðlindarenta“.

Petta er mikilvægt atriði. Рað er aðeins pegar öll fyrirtækin (allar útgerðir eða öll skip) eru komin í hagnað að hægt er að skilgreina hlut hagnaðar og rentu sem „auðlindarentu“. Petta er vegna pess, að pá fyrst er hugsanlega eitthvað sameiginlegt sem áhrif hefur á pann hluta hagnaðar hjá peim. Petta sameiginlega gæti verið hærra (heims)markaðsverð á fiskafla almennt eða betra ástand fiskistofna. Bæði pessi atriði gætu skýrt hærri meðaltekjur, en á mynd 4 virðist sem hærri meðaltekjur á sóknareiningu séu hluti af skýringunni á betri afkomu fyrirtækjanna. En væru petta peir sameiginlegu pættir sem hefðu breyst til batnaðar pá væri pað sýnt á mynd 5 sem hliðrun meðaltekjuferils (MT) til hægri, en um pað er ekki að ræða; MT ferillinn stendur í stað. Á myndum 4 og 5c er í raun aðeins gert ráð fyrir peirri breytingu að útgerðum eða skipum fækkar og pað leiði til minni heildarsóknar, jafnvel pó sókn peirra skipa sem enn eru að veiðum aukist.

Hér hefur heldur ekkert verið útskýrt hvernig skipum er fækkað, pó auðvelt sé að ímynda sér að taprekstur reki suma út. Eingöngu hefur verið nefnt að um breytt skipulag sé að ræða,

\footnotetext{
${ }^{36}$ Pessi lýsing getur hins vegar ekki verið lýsing á langtímajafnvægi greinarinnar, enda hverfa pá fyrirtæki með taprekstur út af markaði og hagnaður eigngerist (capitlization) hjá hagkvæmustu fyrirtækjunum, og pannig hverfur allur hagrænn hagnaður í pví jafnvægi.

37 Pessi ábati væri pá framleiðendaábati, sem gæti lýst rentu eða hagnaði að hluta.

${ }^{38}$ Að einhverju leyti má rekja pessa hugtakanotkun til Ricardo, eða kannski fremur túlkunar Marshall á skrifum hans. Á sama hátt og jarðnæði var mishentugt til kornræktar og pað hentugasta fékk rentu pegar pað óhentugra var ræktað, pá eru fyrirtækin hér mishæf til veiða og pau hæfustu skapa pá rentu. Pannig er óbein tenging við mismunarentu Ricardo. Kenningalega séð er hins vegar ekki um skyldleika að ræða á innrijaðarrentunni hér og mismunarentu Ricardo og Marshall.
} 
horfið er frá opnum aðgangi og í lokaðan aðgang, hugsanlega með frekari stýringu eða öðrum breytingum á fiskveiðstjórn. Ef eingöngu er um pað að ræða að lokað er á nýjar útgerðir, takmörk sett á fjölda skipa, heildarafli tegunda takmarkaður, sóknardagar takmarkaðir, eða aðrar hindranir eða stýringu komið á, pá dregur pað ekki úr sókninni, en hún gæti tekið á sig annað birtingarform (svo sem öflugri skip og veiðafæri).

Hafi hins vegar verið komið á skipulagi eignarréttar, svokölluðu kvótakerfi í fiskveiðum, pá skapast frekari hvatar til að draga úr sókn, draga úr kostnaði við sókn, auka verðmæti afla, o.fl. í pá veru. Pær breytingar sem hvatar af pessum toga skapa myndu flestir leiða til hliðrunar á tekju- og kostnaðarferlum, p.e. tekjur á sóknar- og aflaeiningu myndi hækka og kostnaður lækka. En eins og fyrr segir pá eru tekju- og kostnaðarferlar á myndunum hér óhreyfðir og er ekki beint gert ráð fyrir pessum viðbótaráhrifum af breyttu fyrirkomulagi.

Önnur hlið á pessu mikilvæga atriði er hvernig pessi „auðlindarenta“ verður til og eykst á mynd 5. Eins og áður segir pá er í raun aðeins verið að gera ráð fyrir að skipum eða útgerðum sé að fækka, pær óhagkvæmustu fari út, og pað leiði til minni heildarsóknar. Við petta er MT að hækka og MK og JK að lækka, p.e. færsla eftir ferlunum til vinstri. Afleiðing pessa er að hagnaður í greininni er að aukast. Ef svæði merkt abcd á myndum 5 er skoðað sést að pað stækkar pegar farið er frá 5a í $5 b$ og í 5c, enda er hæðarbilið milli MT og MK að aukast parna. En pað eru einnig breytingar á pví sem við köllum rentu hér, bæði innrijaðarrentunni og „,auðlindarentunni“. Pessari breytingu má lýsa með tvennum hætti. Annars vegar að umfang innrijaðarrentu aukist við færslu frá $4 \mathrm{a}$ til $4 \mathrm{~b}$ en minnki síðan frá $4 \mathrm{~b}$ til 4c, en samhliða pví er umfang auðlindarentunnar, sem svo er kölluð hér, að aukast, fer úr neikvæðri stærð í 4a í núll á 4b og í jákvæða stærð í 4c. Hins vegar má lýsa pessu sem svo að innrijaðarrentan sé alltaf að aukast frá 4a til 4c, en í stað pess að lýsa henni alltaf sem einni stærð pá skiptum við henni í tvo hluta, par sem hinn hlutinn kallast „auðlindarenta“, og miðast sú skipting við umfang sóknar með hliðsjón af skurðpunkti MT og JK ferlana. Pegar umfang sóknar er í fullu samræmi við skurðpunkt MT og JK pá er eingöngu talað um innrijaðarrentu og hinn hlutinn, auðlindarentan er pá núll. Sé hins vegar sókn meiri eða minni en petta er auðlindarentan neikvæð eða jákvæð, og hefur stærð hennar jafnframt áhrif á umfang innrijaðarrentu. M.ö.o. pá er auðlindarentan hér ekkert annað en annað heiti á hluta innrijaðarrentunnar; innrijaðarrenta umbreytist í „,auðlindarentu“.

"Auðlindarentan“ sem hér er að verða til hefur pannig ekkert að gera með auðlindina sjálfa, p.e. fiskistofnana, né hagstæðara heimsmarkaðsverð á fiski (hvað pá innanlandsverð). Hún er fyrst og fremst tilkomin vegna pess að reksturinn er að jafnaði hagkvæmari en áður, par sem lökustu útgerðirnar hafa horfið frá veiðum, og pað er nú skipulag til staðar sem hvetur til meiri skilvirkni í rekstri en áđur.

\section{Kvótakerfi gefa hvata til sköpunar arðs (rentu)}

En a.m.k. einni stórri spurningu er hér enn ósvarað: með hvaða hætti varð breytingin frá 4a til 4c, hvernig var skipunum fækkað? Рað er kannski ekkert eitt svar við pessari spurningu en hér má pó rökstyðja svar sem byggir á líkingu við próunina á Íslandi undanfarna prjá áratugi. Á sama tíma og Íslendingar voru að ná fullum yfirráðum yfir fiskimiðum sínum með útvíkkun landhelginnar í skrefum út í 200 mílur varð peim einnig ljóst að óhófleg sókn gæti leitt hvoru tveggja til tapreksturs og minnkandi fiskistofna. Sífelld stækkun fiskiskipaflotans, hvort heldur með fjölgun, stækkun, eða með annarri útfærslu öflugri skipa 
gat ekki gengið til lengdar, jafnvel pó erlendu skip hyrfu af miðunum. Síldarstofnar hnignuðu á sjöunda áratug síðustu aldar og varð að hætta peim alveg í nokkur ár til pess að reyna að endurreisa stofnana. Рað tókst pó tíma hafi tekið. Reynslunni ríkari var reynt að bregðast fyrr við pegar fiskifræðingar vöruðu við of mikilli sókn í aðrar fisktegundir, sérstaklega porskinn á seinni hluta áttunda áratugarins. Fyrst voru sóknardagar á porskveiðum takmarkaðir, síðan var fjölgun skipa stöðvuð og svo stækkun líka. Prátt fyrir petta varð bæði afkoma útgerðar verri og ástand sumra fiskistofna hnignaði. Í árslok 1983 var loks ákveðið að koma á aflakvótakerfi í botnfiskveiðum tímabundið, fyrst til 1 árs, en síðan framlengt í áföngum, og með allverulegum breytingum til sóknarkvóta, til ársins 1990. ${ }^{39}$ Frá 1991 hefur síðan verið til staðar ótímabundið aflahlutdeildarkerfi og hefur pað náð til mikils meirihluta fiskveiðanna (Birgir Pór Runólfsson, 1999).

Pó augljóst mál sé frá hagfræðilegu sjónarhorni að aflakvótakerfi sé pað skipulag sem leiðir til hvað mestrar hagkvæmni í fiskveiðum pá er pað nú ekki svo að slík skipulagsbreyting eigi sér stað vegna röksemda hagfræðinga. ${ }^{40}$ Megin ástæða pess að kvótakerfi er komið á er neyð, að taka parf á vanda fiskveiða, oftast ofveiði. ${ }^{41}$ pegar pað blasir t.d. við að fækka parf skipum við veiðarnar, pá virðist oft auðveldast fyrir stjórnvöld að veita hverju skipi sinn skammt. Pannig var pað hérlendis. Fyrir árið 1984 var öllum stærri veiðiskipum úthlutaður skammtur (hlutdeild) í helstu botnfisktegundum sem heildaraflamark var á. ${ }^{42}$ Pessi úthlutun byggði á aflareynslu undanliðinna 3 ára, en pau ár hafði botnfiskafli verið mjög mikill. Porskaflinn hafði verið um 400 púsund tonn (að jafnaði) árlega undanliðin prjú ár, en á haustmánuðum 1983 lögðu fiskifræðingar til 200 púsund tonna heildaraflamark í porski vegna ársins 1984. Parna var pví boðuð um 50\% skerðing í porski og pað til handa heldur fleiri og öflugri skipum en höfðu að jafnaði stundar veiðar pessi undanliðin ár.

Skerðing á skip var hlutfallsleg og pví ljóst að skip urðu að mæta samdrætti í tekjum með minnkun kostnaðar, verðmætari afla, eða sameiningu aflaheimilda á færri skip. Veik staða marga útgerða varð líka til pess að hvetja til sameiningar aflaheimilda, bæði með yfirtöku og sameiningu fyrirtækja. Pó heldur hafi ræst úr með botnfiskafla næstu ár á eftir, pá hélt sú próun áfram að sameina aflaheimildir á skip. Próun í pessa veru varð enn hraðari eftir 1990, bæði vegna pess að niðursveifla varð í ástandi fiskistofna en einnig vegna nýrrar löggjafar sem gerði kvótakerfið varanlegra og víðtækara, og setti pað pannig á tryggari stoðir en áður. Afleiðingin varð, að á heildina litið fækkaði skipum og heildarsókn minnkaði. Gæti petta útskýrt aukinn hagnað, eða „,auðlindarentu“, í fiskveiðunum hérlendis?

Ef svo er, pá parf að hafa í huga hvernig komist var í pessa stöðu. Ríkisvaldið kom ekki einfaldlega upp girðingum og rak fjölda útgerða af miðunum og leyfði hinum sem eftir voru að „hirða upp“ auðlindaarð og pað án mikillar fyrirhafnar. Enginn var rekin út, en í staðinn var pað lagt á útgerðir að bera kostnaðinn. Við sameiningu aflaheimilda á skip tóku útgerðir á sig viðbótarútgjöld, en pau geta falist í kaupum á kvóta, kaupum á öðrum útgerðarfélögum, fækkun skipa, o.fl.. Petta er jafnan framkvæmt með skuldsettri fjárfestingu til lengri tíma. ${ }^{43}$

\footnotetext{
39 Pegar síldveiðar hófust að nýju 1975 var byggt á aflakvótum og árið 1989 var aflakvótum komið á í loðnuveiðum.

40 Sjá Arnason (2007) um samspil eignarréttinda og hagkvæmni í fiskveiðum.

${ }^{41}$ Sjá líka Anderson \& Libecap (2010), Anderson o.fl. (2011), Libecap (2003, 2008) og Hannesson (2004).

42 Árið 1984 var viðmið um stærð 10 brúttórúmlestir, en var lækkað í 6 brl. árið 1991.

${ }^{43}$ Hér er að sjálfsögðu einfaldað nokkuð í frásögninni. Margt fleira gerðist samtímis innleiðingu kvótakerfis í botnfiskveiðunum og í framhaldi pess. M.a. frjáls verðlagning fiskafla og tilkoma
} 
Aukinn framtíðarhagnaður átti síðan að standa undir peirri fjárfestingu. Arðurinn, sem alla jafna væri tilgreindur sem „auðlindarenta,“ er að miklum hluta tilkomin vegna pessa fyrirkomulags, p.e. að útgerðir urðu að fjárfesta, að kaupa aðrar útgerðir út eða a.m.k. kvóta peirra. Viðskipti með aflahlutdeildir leiða til pess að pær útgerðir sem hagkvæmastar eru og mestan arð (rentu) geta skapað eignast kvótann; pær kaupa út útgerðir sem ekki telja sig geta skapað sömu verðmæti. ${ }^{44}$

\section{Lokaorð}

Ljóst er að mikil umskipti hafa orðið í sjávarútvegi Íslendinga undanfarna prjá áratugi, eða á peim sama tíma og skipulag aflahlutdeildarkerfis var innleitt og fest í sessi. Rétt fyrir upphaf pessa tímabils hafði fiskafli Íslendinga reyndar náð nýjum hæðum, sem pó skilaði sér ekki í bættri afkomu sjávarútvegsins. Afli minnkaði síðan enda ástand fiskistofna hnignandi. Aflahlutdeildarkerfi var innleitt í nokkrum smáum og misjafnlega markvissum skrefum. Á sama tíma hafa einnig orðið miklar breytingar á öðrum sviðum sjávarútvegsins, eins og áður segir, sem sumar tengjast tilvist og próun kvótakerfisins en aðrar eru pví pó ótengdar.

Á pessu tímabili hefur orðið mikil breyting í veiðimynstri, meðferð og nýtingu afla, og aukin sókn í nýjar fisktegundir sem sumar póttu síður álitlegar áður. Frelsi í viðskiptum með afla og afurðir var komið á og afskipti sveitarfélaga og ríkis af fjármögnun og rekstri sjávarútvegs eru nú hverfandi en voru mjög ríkjandi áður. Breytingar hafa einnig orðið í flota veiðiskipa, bæði með fjárfestingum til að breyta eldri skipum og einhverjum nýjum sem komið hafa í stað eldri skipa. Um tíma var mikil áhersla á vinnsluskip en hin síðari ár hefur peim fækkað aftur, og reyndar nokkuð í takt við fækkun skipa almennt í veiðiflotanum. Kvótakerfið og minni heildaraflaheimildir hafa skapað margskonar hvata til hagræðingar, sérhæfingar, aukinnar nýtingar, vörupróunar og markaðsstarfs. Petta hefur skilað sér í lægri kostnaði við veiðar og vinnslu, en jafnframt auknum tekjum. Verðpróun afurða á alpjóðlegum mörkuðum hefur auðvitað hjálað til en íslensk sjávarútvegsfyrirtæki virðast hafa staðið sig betur að jafnaði í pessum efnum en fyrirtæki annarra pjóða. ${ }^{45}$ Óhætt er að fullyrða að skipulag byggt á lóðréttri sampættingu fiskvinnslu og útgerðar á par stóran hlut að máli.

Nútíma sjávarútvegur parf að byggja á góðum stoðum. Gott ástand fiskistofna skiptir par auðvitað máli, en gott ástand peirra byggir ekki bara á ráðgjöf fiskifræðinga heldur ekki síður pví að sjávarútvegsfyrirtæki hafi hag af öflugri fiskistofnum. Aflahlutdeilarkerfi sem byggir á varanlegum og framseljanlegum kvótum er ein mikilvægast stoð pessa. Рað kerfi er líka mikilvæg stoð pess að hér haldi áfram að byggjast upp öflug og samkeppnihæf sjávarútvegsfyrirtæki sem geti náð framúrskarandi árangri á alpjóðlegum mörkuðum. Á

ferskfiskmarkaða, minnkun og svo afnám hafta í sölu fiskafurða til útlanda, opinberir aðilar draga sig að mestu út úr sjávarútvegsrekstri. Pá er innleidd breytt tækni í veiðum og vinnslu, vinnsluskip, fjölveiðiskip, sérhæfing verður meiri og margt fleira. Sumt af pessu er óháð kvótakerfinu en annað byggir á hvötum tengdum pví.

${ }^{44}$ Verð sem myndast á aflahlutdeildum byggir pví ekki einvörðungu á mati útgerða á ástandi og virði fiskistofna til framtíðar, heldur líka á innrijaðarrentunni (sem við erum að nefna „,auðlindarentu“ hér). Núverandi útgerðir meta kvóta á hærra verði en pær útgerðir sem frá hverfa, vegna pess að pær hafa meiri hagkvæmni. Innrijaðarrentan eigngerist pví í virði kvótans.

${ }^{45}$ Sjá t.d. umfjöllun um rannsóknir á virðiskeðjunni og lóðréttri sampættingu í Hagfræðistofnun (2011), og jafnframt í peim heimildum sem par er vitnað til. 
slíkum stoðum getur ekki aðeins útgerðin heldur sjávarútvegurinn allur skapað pjóðinni mikinn arð.

Hvort sem við kjósum að kalla pennan arð „auðlindarentu“ eða einhverju öðru heiti er ekki aðalatriði. Раð skiptir hins vegar miklu að átta sig á pví að án öruggra og varanlegra aflaheimilda parf enga umræðu um „,auðlindarentu, “ pví hún mun pá örugglega minnka eða hverfa alveg. Traust kvótakerfi mun hins vegar skila sér í aukinni arðsköpun. En pað verður aldrei auðvelt, og jafnvel er pað útilokað, að aðgreina hlut einstakra auðlinda (framleiðslupátta) í peirri arðsköpun. 


\section{Heimildaskrá}

Alchian, A. A. (1991). Rent. In J. Eatwell, M. Milgate, \& P. Newman (Eds.), The new Palgrave: The World of Economics. London: MacMillan Press. 591-597

Anderson, L.G. (1989). Conceptual Constructs for Practical ITQ Management Policies, Neher, P.A., Arnason, R. og Mallett, N. ritstj., Rights Based Fishing. The Netherlands: Kluwer Academic Publishers, 191-209.

Anderson, T. L., Arnason, R. \& Libecap, G. D. (2011). Efficiency Advantages of Grandfathering in Rights-Based Fisheries Management. Annual Review of Resource Economics, vol. 3: 159-179

Anderson, T. L. \& Libecap, G. D. (2010). The allocation and dissipation of resource rents: Implications for fishery reform. Leal, D. ritstj. Political Economy of Natural Resource Use: Lessons for Fisheries Reform. Washington:The International Bank for Reconstruction and Development / The World Bank, 79-96

Anderson, T. L. \& McChesney, F. S. ritstj. (2003). Property Rights: Cooperation, Conflict, and Law. New Jersy: Princeton University Press.

Arnason, R. (2000). Property rights as a means of economic organization. In Use of Property Rights in Fisheries Management: Proceedings of the FishRights 99 Conference, ed. R Shotton. Freemantle: Western Australia, 11-19 November 1999. FAO Fisheries Technical Paper 404/1. Rome: FAO

Arnason, R. (2002). Resource Rent Taxation: Is it Really Nondistortive? Ritgerð vegna erindis flutt á 2. heimspingi umhverfis og auðlindahagfræðinga, Monterey, Kalfornía, 24.-27. júní

Arnason, R. (2007). Property rights quality and economic efficiency of fisheries management regimes: Some basic results. Í Advances in Fisheries Economics, T. Bjorndal, D. Gordon, R. Arnason, R. Sumaila, ritstj. Oxford:Blackwell Publishing, 32-58

Arnason, R. (2011). Loss of economic rents in the global fishery. J. Bioecon 13:213-232

Birgir Pór Runólfsson. (1999) Sjávarútvegur Íslendinga : próun, staða og horfur. Reykjavík: Sjávarútvegsráðuneytið.

Blaug, Mark. (1997). Economic Theory in Retrospect. 5. útg. Cambridge: Cambridge Univ. Press.

Coglan, L., \& Pascoe, S. (1999). Separating resource rents from intra-marginal rents in fisheries' economic survey data. Agricultural and Resource Economics Review, 28, 219-228.

Coglan, L., \& Pascoe, S. (2002). Efficiency of Fishing Vessels in the English Channel. American Journal of Agricultural Economics, Vol. 84, No. 3 (Aug.), 585-59 
Desai, M. (2008). Profit and profit theory. Í Durlauf, S. N. \& Blume, L. E., ritstj., The New Palgrave Dictionary of Economics, 2. útg.

Ekelund, R. B. \& Hébert, R. F. (2007). A History of Economic Theory and Method, 5. útg. Long Grove, Ill. : Waveland Press

Fetter, F. A. (1977). Capital, Interest, and Rent: Essays in the Theory of Distribution. Endurskoðuð útgáfa, Murray N. Rothbard, ritstj. Kansas City: Sheed Andrews and McMeel.

Gordon, H.S. (1954). The Economic Theory of a Common Property Resource: the Fishery. Journal of Political Economy 62(April): 124-142.

Hagfræðistofnun. 2011. Fjárhagslegur aðskilanaður veiða og vinnslu: Kostir og gallar. Skýrsla C11:01. Reykjavík:Hagfræðistofnun Háskóla Íslands.

Hannesson, Rögnvaldur (2004). The Privatization of the Oceans. Cambridge, MIT Press.

Hardin, G. (1968). The Tragedy of the Commons. Science 162 (December): 1243-1248.

Herrmann, M. (1996). Estimating the induced price increase for Canadian Pacific halibut with the introduction of the individual vessel quota program. Canadian Journal of Agricultural Economics, 44(2), 151-164.

Herrmann, M., \& Criddle, K. (2006). An econometric market model for the Pacific halibut fishery. Marine Resource Economics, 21(2), 129-158.

Homans, F. R., \& Wilen, J. E. (2005). Markets and rent dissipation in regulated open access fisheries. Journal of Environmental Economics and Management, 49(2), 381-404.

Johnson, R.N. (1995). Implications of Taxing Quota Value in an Individual Transferable Quota Fishery. Marine Resource Economics 10(4):27-340.

Johnson, Ronald N., and Gary D. Libecap. 1982. Contracting Problems and Regulation: The Case of the Fishery. American Economic Review 72(5): 1005-1022.

Kittrell, E. R. (1957). Ricardo and the Taxation of Economic Rents. American Journal of Economics and Sociology, vo. 16, no. 4 (Júlí), 379-390.

Knight, F.H. (([1921] 1971). Risk, Uncertainty and Profit. New York and Boston: Houghton Mifflin Co. (Republished, with Foreword by George J. Stigler, University of Chicago Press, 1971)

Landreth, H. \& Colander, D. C. (2002). History of Economic Thought. 4. útg. Boston: Houghton Mifflon Co. 
Lewin, P. \& Phelan, S. E. (2002). Rent and Resources: A Market Process Perspective. Foss, N. J. \& Klein, P.G., ritsti. Entrepreneurship and the Firm: Austrian perspectives on economic organization. Cheltenham: Edward Elgar, 221-247.

Libecap, G. (2003). Contracting for Property Rights. Í Anderson, T. L. \& McChesney, F. S. ritstj. Property Rights: Cooperation, Conflict, and Law. New Jersy: Princeton University Press, 142-167.

Libecap, Gary D. (2008). Open-Access Losses and Delay in the Assignment of Property Rights. Arizona Law Review 50, 379-408.

Lippman, Steven A. \& Rumelt, Richard P. (2003). The payments perspective: microfoundations of resource analysis. Strategic Management Journal, 24 (10), 903-927.

Matthews, John. (2006). Strategizing, disequilibrium, and profit. Stanford: Stanford University Press.

Ricardo, D. (([1821] 1965). Principles of Political Economy and Taxation. 3. útg., London: Dent Dutton.

Rima, Ingrid. (2009). Development of Economic Analysis. 7. útg. New York:Routledge.

Schumpeter, Joseph A. ([1911] 1934). The theory of economic development: An Inquiry into profits, capital, credit, interest, and the business cycle. Cambridge : Harvard University Press.

Schumpeter, Joseph A. ([1954] 1986). History of Economic Analysis. Oxford University Press.

Screpanti, E. \& Zamgni, S. (2005). An outline of the history of Economic Thought. 2. útg. Oxford: Oxoford University Press.

Simon, Julian L. (1981) The Ultimate Resource. Princeton N.J.:Princeton University Press.

Trailer, J. (2003). On the Theory of Rent and the Dynamics of Profitability, 21st International System Dynamics Society Conference Proceedings. System Dynamics Society (systemsdynamics.org).

Pjóðhagsstofnun. (1988). Sögulegt yfirlit hagtalna 1945-1986. Reykjavík : Pjóðhagsstofnun.

Pjóðhagsstofnun. (1991) Sögulegt yfirlit hagtalna 1945-1988. Reykjavík:Pjóðhagsstofnun.

Pjóðhagsstofnun. (1998). Sögulegt yfirlit hagtalna 1945-1997. Reykjavík:Pjóðhagsstofnun. 